\title{
КРИТЕРІЇ ОЦІНКИ, ПОКАЗНИКИ ТА РІВНІ ПСИХОЛОГІЧНОЇ ГОТОВНОСТІ МАЙБУТНІХ ПЕДАГОГІВ ДО ПРОФЕСІЙНОЇ САМОРЕАЛІЗАЦІї
}

\section{Гуртовенко Наталія Вікторівна}

Викладач психології Уманського медичного коледжу, м. Умань (Украӥна)

\begin{abstract}
Анотація. У статті обтрунтовується вибір критерїв оцінки, показників та рівнів готовності до професійної самореалізаиії у майбутніх педагогів. Зазначається, щзо психологічна готовність майбутнього педагога до професійної самореалізації представляє собою наявність певних індивідуально-особистісних якостей, на базі яких відбувається процес підготовки до професійної самореалізації під час його навчання у виші та формування професійно важливих якостей особистості. Виокремлення блоків якостей, необхідних для сформованості психологічной готовності до професійної самореалізації дозволив визначити та обгрунтувати критерії оцінки $з$ відповідними їм показниками: комунікативний критерій (вміння налагодити контакт $i$ взаємодіяти з ближнім на вербальному та емпатійному рівнях); емочійно-вольової критерій (емпатія, настрій, емоційна стійкість, стійкість до стресових ситуаџій, життєрадісність, стійка психіка і т.п.); інтелектуально-смисловий критерій (високий рівень інтелекту, ерудиція, розвинене мислення, аналітичний склад розуму, рефлексія); мотиваційно-пізнавальний критерій (креативність, адекватна самооцінка, винахідлвість, високий рівень мотивації досягнення, допитливість, ініціативність, прагнення до саморозвитку та самореалізації); морально-етичний критерій (чуйність, відповідальність, ввічливість, тактовність, людяність, чесність, альтруїзм, безкорисливість, доброзичливість, працьовитість, щүирість, людяність).
\end{abstract}

Ключові слова: критерї оцінки, показники, рівні готовності, психологічна готовність, професійна самореалізація, майбутні педагоги.

\section{Постановка проблеми у загальному} вигляді та її зв'язок із важливими науковими чи практичними завданнями. Особливості кожної професійної діяльності створюють певні умови для розвитку особистості i процесу професійного становлення, який у свою чергу, впливає на особливості іiі розвитку, іiі самореалізацію на обраному шляху. У зв'язку з цим однією 3 найважливіших задач у психологічній науці залишається вивчення професійної самореалізації, яка передбачає суттєві зміни 
особистості людини у становленні і подальшому розвитку професійної діяльності. Як будь-який інший процес, професійна самореалізація характеризується якісними внутрішніми перетвореннями, які забезпечують відповідну роботу людини у іiі професійній діяльності.

Особливий інтерес представляє концепція самореалізації як процесу переживання цінностей професійної діяльності, що містить інтелектуально-смисловий, мотиваційно-потребнісний, активнодіяльнісний і креативно-пізнавальний аспекти. При цьому важливо наголосити на необхідності вивчення феномена самореалізації особистості 3 врахуванням специфіки кожної конкретної діяльності, а також специфіки конкретних історичних, соціально-демографічних, економічних умов, в яких розвивається особистість, оскільки навколишнє середовище обумовлює прояв активності людини.

Незважаючи на те, що адаптація до умов роботи на конкретних місцях відбувається на основі основного багажу знань та вмінь, одержаних у виші, важливу роль, а часом одну 3 головних, відіграє наявність у молодого фахівця готовності до професійної діяльності взагалі і професійної самореалізації зокрема [1-4 та ін.]. Саме тому в умовах реформування вищої освіти, забезпечення конкурентоспроможності фахівців на ринку праці особливої актуальності набуває проблема формування психологічної готовності майбутніх педагогів до професійної самореалізації.

Аналіз останніх досліджень і публікацій, в яких започатковано розв'язання даної проблеми і на які спирається автор. Професійна самореалізація - це пошук i знаходження свого місця у системі людських знань, досягнення поставлених цілей $\mathrm{y}$ професійній діяльності, а також особистісне самовизначення. Професійна самореалізація передбачає зміну себе, власної професійної позиції, подолання перешкод, що виникають у професійній діяльності. Феномен професійної самореалізації у сучасній філософії, психології та педагогіці в основному вивчається у двох аспектах: 3 боку його компонентів - цілі, мотиви, процес досягнення мети, і 3 боку результатів - станів особистості. На цей час дослідження самореалізації особистості, певної діяльності проводились на вікових: учнів (В. П. Завада, М. Ю. Рись), студентів (Е. В. Бакієва, К. Е. Безукладніков, Л. Х. Гудієва, В. М. Журавчик, І. Л. Беккер, О. В. Коломієць, I. В. Лебедик, Г. А. Лєвова, К. А. Поселецька, О. В. Торшевська, С. М. Усова); гендерних (B. А. Гупаловська, О. М. Мірошніченко, О. Г. Угрін) та професійних групах: педагогів (О. В. Волошенко, С. В. Калашнікова, 3. Ю. Крижановська, Т. В. Куценко, С. О. Мулькова, В. I. Хрипун, М. І. Ярославцева); психологів (О. Ф. Бондаренко, I. В. Коновалова, 
А. Б. Косарєва, М. М. Радул, О. Д. Сафін, Я. В. Чаплак); в економічній діяльності (О.В.Іващенко, О.В. Мелешко), творчих професіях (Т. В. Андрєєва, Т. П. Вівчарик), невиробничій сфері суспільства (О.О.Ідінов), особливих видах праці (О. В. Пітерська). В усіх цих дослідженнях підкреслюється, що професійна самореалізація - це пошук i знаходження свого місця у системі людських знань, досягнення поставлених цілей у професійній діяльності, а також особистісне самовизначення.

Професійну реалізацію у психології розглянуто 3 різних 3 точок зору. Так наприклад, представники особистісного підходу (Б. Г. Ананьєв, Л. І. Божович, В. С. Мерлін, О. М. Леонтьєв, І. П. Маноха та ін.) на перше місце ставлять людину, у якій 3 самого початку закладено прагнення до самовизначення, саморозвитку, самопізнання i самореалізації. Людина усвідомлює свої мотиви i потреби, власну життєву позицію i відповідає їй, вона сама вільна у своєму виборі та обирає свій життєвий шлях. Тут ми стикаємося 3 мотиваційною складовою, яка впливає на самовизначення людини. I майбутній фахівець, обираючи професію, розуміє, чи може він відповідати їй за своїми індивідуальними характеристиками, здібностями, темпераментальними особливостями, тому важливим є враховування своїх бажань і можливостей [5-8]. Майбутній педагог перш за усе сам повинен відповісти собі на питання - чи готовий він психологічно до виконання такої важкої, складної, десь непередбачуваної професії, чи зможе він реалізувати себе у ній, досягти свого «акме», чи відповідає він, перш за усе особистісним характеристикам і вимогам до цієї професії.

Представники діяльнісного підходу (К. О. Абульханова-Славська, О. О. Бодальов, В. О. Бодров, А. В. Брушлинський, В. В. Давидов, Ю. М. Забродін, Є. О. Клімов, Л. М. Мітіна, С. Л. Рубінштейн, В. Д. Шадриков та ін.), розглядають самореалізацію під кутом професійної діяльності. Тут успішність професійної діяльності розглядається через здібності, які допомагають в іiі здійсненні, необхідно активно застосовувати ці здібності і по можливості вдосконалювати і розвивати їх. Тут студенту важливо зрозуміти, наскільки активно він готовий брати участь у майбутній професійній діяльності, самореалізуючись у ній. Необхідно зауважити, що прихильники діяльнісного підходу приділяли увагу i індивідуально-психологічним особливостям у професії.

У межах вікового підходу становить інтерес розгляд професійного становлення як процесу і як результату. П. П. Блонський, Л. С. Виготський, П. Я. Гальперін, Д.Б. Ельконін та ін. дотримуються думки, що оскільки особистісне становлення охоплює весь життєвий шлях людини, то професійна та особистісна самореалізації $є$ невіддільними. 
Вони розглядали становлення як поетапний процесс, який $є$ безперервним i постійно рухається.

Професійно орієнтований підхід Є. Ф. Зеєр, С. О. Клімова, Н.С. Пряжникова та ін. заснований на визнанні нерозривного взаємозв'язку людини і професії, з врахуванням відповідності людини виконуваній нею професійної діяльності. Зазначений підхід дозволяє побачити взаємозв'язок людини i професії через професійну придатність, тобто психологічну готовність майбутнього педагога до виконання діяльності, яка повинна зводитися до розуміння та усвідомлення ним значущості своєї професії, готовності до подолання труднощів при вступі у професію, адекватно оцінювати себе і свої сили, щоб бачити та освоювати нові професійні рубежі.

Заслуговує на увагу гетентикомоделюючий і суб'єктно орієнтований підходи до професійної самореалізації особистості (С. Д. Максименко, B. I. Осьодло), які отримали потужний розвиток в Україні останніми роками [9-10].

\section{Виділення невирішених раніше} частин загальної проблеми, яким присвячується стаття. На сьогодні процес формування психологічної готовності майбутніх педагогів до професійної самореалізації, їхні психологічні резерви і потенційні можливості вивчено недостатньо, зокрема, не на належному рівні враховуються особистісні якості, здатність до виокремлення i врахування власного «Я», наявність адекватного образу майбутньої професійної діяльності, усвідомлення вимог, що пред'являються професією до особистості професіонала на етапі навчання у педагогічному виші. У зв'язку з цим дослідницький інтерес представляє структура і зміст психологічної готовності майбутнього педагога до професійної самореалізації.

Мета статті - обгрунтування вибору критеріїв оцінки, показників та рівнів готовності майбутніх педагогів до професійної самореалізації.

Виклад основного матеріалу дослідження 3 повним обгрунтуванням отриманих наукових результатів. Теоретичний аналіз літератури з питання дослідження індивідуально-особистісних особливостей педагогів дозволив узагальнити їх і виявити головні, які були виокремлено за допомогою контент-аналізу: комунікативність, емпатія, високий рівень інтелекту, прагнення до саморозвитку та самореалізації, відповідальність, адекватна самооцінка.

$$
\text { Спілкування як складний, }
$$

багатоплановий процес встановлення і розвитку контактів між людьми обумовлює для педагога одну 3 базових якостей, що зумовлює весь процес роботи 3 людиною комунікативність. У спілкуванні виокремлюють три аспекти: перцептивний, комунікативний та інтерактивний. Комунікативний аспект спілкування пов'язаний 3 виявленням 
специфіки інформаційного процесу між людьми як активними суб'єктами. Засобами комунікативного процесу $\epsilon$ різні знакові системи: мова, оптикокінетічна система (жести, міміка, пантоміміка), паралінгвістічна та екстралінгвістичні системи, система організації простору i часу комунікації, система «контакту очей».

Емпатію одні відносять як якість - до професійно важливих, інші - до індивідуально-особистісних. На думку К. Рождерса, бути в змозі емпатувати означає сприймати внутрішній світ іншого точно, зі збереженням емоційних і смислових відтінків. Неначе стаєш цим іншим, але без втрати відчуття «начебто». Так, відчуваєш радість або біль іншого, як він їх відчуває, і сприймаєш їхні причини, як він їх сприймає. Але, на думку К. Роджерса, обов'язково повинен залишатися відтінок «начебто» [11].

Під емпатією ми розуміємо розуміння емоційного стану, проникненнявчувствування у переживання іншої людини. Хотілося б відзначити, що ця риса у трійці найбільш важливих для педагога. Вміння емоційно привернути до себе людину і дати відчути їй спокій і психологічну підтримку є не менш важливим завданням педагога [12].

Високий рівень інтелекту педагога, на думку багатьох вчених (В. М. Дружинін, Р. Мей, М. М. Обозов та ін.) є одним 3 головних критеріїв, необхідних для його успішної діяльності. Багато вчених виокремлюють прагнення до саморозвитку i самореалізації (за А. Маслоу - самоактуалізація) як важливу особистісну i, в певному сенсі, професійну якість. Як зазначає А. Маслоу, у кожної людини існує прихований потенціал, необхідно лише прагнути до його повного розкриття, а це залежить у першу чергу, від мотивації. Звичайно, успішність та ефективність діяльності безпосередньо залежить від бажання i прагнення педагога відбутися як особистість $\mathrm{i}$ як професіонал.

Більшість вчених виокремлюють таку якість, як відповідальність і вважають іiі однією з основних якостей людини. У вимогах до професії «педагог» ця якість стоїть одним 3 перших і багато вчених (М. О. Амінов, Є. О. Клімов, М. В. Молоканов, В. Ф. Сафін та ін.) підтверджують це. Педагог не може безвідповідально підходити до вирішення питання, не може порушувати етичний кодекс, не має права на помилку, тому, що психічний стан вихованця, його доля і життя вимагають відповідального підходу. Також, більшість вчених зазначають обов'язкову наявність адекватної самооцінки у педагога, так як адекватне сприйняття, перш за усе себе, своїх здібностей, можливостей, особистісних якостей дає можливість не лише допомогти знайти правильне рішення для іншої людини, але і самому педагогу працювати над собою, самовдосконалюватися, формувати свою життєву позицію, знати про свої недоліки і 
працювати над їхнім усуненням.

Один 3 головних критеріїв психологічної готовності майбутнього педагога до професійної самореалізаії, його зрілості як фахівця у своїй галузі, $\epsilon$ професійна готовність, тобто ступінь відповідності змісту і стану його психіки i фізичного здоров'я якісним вимогам виконуваної професії. К. К. Платонов зазначав, що професійна готовність фахівця це суб'єктивний стан особистості, яка вважає себе здатною і підготовленої до виконання відповідної професійної діяльності та прагне їі виконувати [13]. Основними компонентами професійної готовності психіки фахівця є:

- орієнтовний, інтелектуальнопізнавальний (певний рівень професійного розвитку пізнавальної сфери особистості фахівця: професійне сприйняття, мислення, уява і т. п.).

- спонукальний, потребністномотиваційний (професійна спрямованість особистості, сила докладених зусиль, ступінь старанності у діяльності, тобто мотиваційна готовність, яка виражається у розумінні сенсу своєї професії, спеціальності, позитивне ставлення до неї, адекватна самооцінка);

- виконавчий (містить професійну майстерність, тобто сукупність професійноважливих якостей, знань, вмінь і навичок, звичок професійної поведінки, необхідний рівень розвитку професійно важливих якостей, здібностей саморегуляції поведінки i діяльності).

Особливу роль у психологічній готовності майбутнього педагога до професійної самореалізації відіграє комунікативна готовність, яка передбачає наявність у професіонала достатнього рівня розвитку вмінь і навичок ефективної контактної взаємодії 3 людьми і професійним середовищем.

У сучасних дослідженнях вчені виокремлюють такі основні психологічні передумови досягнення успіху: мислити категоріями успіху; набути впевненості у собі; активізувати сильну мотивацію досягнення; кожну перешкоду перетворювати у трамплін для досягнення мети; твердо знати, чого необхідно досягти [14].

Виходячи 3 вище викладеного матеріалу, можна зробити висновок про те, що психологічна готовність майбутнього педагога передбачає наявність певних індивідуально-особистісних якостей, на базі яких має здійснюватися процес підготовки до професійної самореалізації під час його навчання у виші, формування у нього професійно важливих якостей особистості. Виокремлюючи блоки якостей, необхідних для сформованості психологічної готовності до професійної самореалізації, можна сформулювати її критерії оцінки та показники:

- комунікативний критерій (вміння налагодити контакт і взаємодіяти з ближнім на вербальному та емпатійни рів- 
нях);

- емоційно-вольової критерій (емпатія, настрій, емоційна стійкість, стійкість до стресових ситуацій, життєрадісність, стійка психіка і т.п.);

- $\quad$ інтелектуально-смисловий критерій (високий рівень інтелекту, ерудиція, розвинене мислення, аналітичний склад розуму, рефлексія);

- $\quad$ мотиваційно-пізнавальний критерій (креативність, адекватна самооцінка, винахідливість, високий рівень мотивації досягнення, допитливість, ініціативність, прагнення до саморозвитку та самореалізації);

- морально-етичний критерій (чуйність, відповідальність, ввічливість, тактовність, людяність, чесність, альтруїзм, безкорисливість, доброзичливість, працьовитість, щирість, людяність).

Відповідно, рівні сформованості психологічної готовності до професійної самореалізації виокремлені за кожним блоком:

\section{1. Коммунікатівний критерій:}

високий рівень: вміння налагодити контакт 3 людиною, взаємодіяти 3 нею на вербальному та емпатійному рівнях, високий рівень товариськості, високий рівень довіри, незалежність суджень i думок, прямолінійність;

середній рівень: вміння налагодити контакт, але в окремих випадках, не 3 перших хвилин, контакт може налагодити не 3 кожним, мало спілкується, сором'язливий;

низький рівень: не може налагодити контакт взагалі, складнощі у взаємодії з іншими на вербальному рівні, мовчазний, недовірливий, замкнутий, має залежність суджень і думок.

2. Емоційно-вольовий критерій:

високий рівень: емпатія розвинена дуже добре, переважання хорошого позитивного настрою, висока емоційна стійкість до дратівливих чинників і дій з боку оточуючих, висока стійкість до стресових ситуацій, життєрадісність, оптимізм, високий рівень самоконтролю, сміливість, стійка психіка, спокійне ставлення до ситуації, виражена сила «Я», організованість, відсутність безпричинної напруженості, впевненість у собі;

середній рівень: середня вираженість емпатії, переважання зміни настрою, але частіше настрій позитивний, іноді важко контролювати свої емоції і ситуацію, пов'язану з ними, що свідчить про середній рівень стійкості до стресової ситуації і невисоку емоційну стійкість, бувають моменти невпевненості у собі і в правильності власних вчинків, існує зрідка невелика напруженість i тривожність по відношенню до ситуації $\mathrm{i}$ оточуючих людей;

низький рівень: слабка вираженість емоційного співпереживання (емпатія), переважання пригніченого настрою або часта 
зміна настрою, слабка емоційна стійкість до дратівливих чинників, низький рівень самоконтролю, невпевненість у власних силах, підвищена тривожність і напруженість.

3. Інтелектуально-смисловий критерій: високий рівень: високий рівень інтелектуального розвитку, прекрасна кмітливість і швидкість розумових операцій, високий рівень креативності, практичність, високий рівень загальної ерудиції, високо розвинене мислення, аналітичний склад розуму, висока здатність до рефлексії, прагнення до перетворення, удосконалення, впровадження нового у вирішення проблем;

середній рівень: добре розвинена креативність, добре розвинені інтелектуальні здібності, наявний певний рівень ерудиції, але деколи не вистачає знань для інформування людини і пояснення їй причин поведінки У ситуації, що склалася, невисока швидкість розумових операцій, мислення розвинене відповідно із середнім рівнем, існує здатність до рефлексії, не завжди є бажання пробувати прогресивні методи для вирішення ситуації, швидше i простіше йти вже перевіреними методами;

низький рівень: низький рівень креативності, у зв'язку з цим винахідливість проявляються дуже слабо або відсутня зовсім, недостатньо розвинені інтелектуальні здібності для педагогічної діяльності (низький рівень інтелекту), не вистачає знань (загальної ерудиції) навіть у загальновідомих областях, непрактичність, слабо розвинене мислення (операції, види мислення), відсутня рефлексія, немає ніякого прагнення перетворювати чи удосконалити методи, застосування стандарту і шаблону до усіх ситуацій.

4. Мотиваційно-пізнавальний критерій: високий рівень: індивідуальний і комплексний (різносторонній) підходи до розв'язуваної проблеми, адекватна самооцінка, винахідливість, схильність до спокійного, але твердого відстоювання своєї думки, допитливість, ініціативність, високий рівень мотивації досягнення, прагнення до саморозвитку і самореалізації в особистісному і професійному аспектах;

середній рівень: підхід до вирішення проблеми здійснюється шляхом вивчення проблеми і виявлення iï головної ланки, самооцінка дещо завищена або занижена; в основному створюються не нові конструкти, а застосовуються старі шаблони, слабко виражена ініціативність, схильність до залежності, ніж до відстоювання своєї думки, мотивація не прагнути до високого рівня досягнення, можливо, і існує прагнення до саморозвитку та самореалізації, але воно не здійснюється через якісь причини;

низький рівень: підхід до проблеми розглядається лише у межах ситуації, боячись вийти за іiі рамки, відсутність комплексного вирішення проблеми, самооцінка сильно завищена або занижена, неможливість відстояти перед іншим свою думку, або 
навпаки диктаторське нав'язування своєї думки ігшому, безініціативність, мотивація уникнення невдачі, немає навіть прагнення до саморозвитку своєї особистості і до самореалізації.

\section{5. Морально-етичний критерій:}

високий рівень: чуйність, ввічливість, щирість, гуманність, тактовність, людинолюбство, чесність, альтруїзм, безкорисливість, доброзичливість, відкритість, довіра. Високий рівень моральної відповідальності, який говорить про те, що життя i доля людини довірена педагогу як найближчій на конкретний момент часу людині. Обов'язкове дотримання норм і правил моралі, а так само етичного кодексу педагога ( «принцип нанесення шкоди», «принцип професійної компетентності», «принцип конфіденційності», «принцип наукової обгрунтованості та об’єктивності», «принцип поваги» та ін.);

середній рівень: недостатня обізнаність про морально-етичні постулати i, як наслідок, не завжди обов'язкове виконання їx, недотрмання чесності i порядності, недостатньо розвинене почуття відповідальності, неповне усвідомлення особистої відповідальності, рідкісне, але порушення принципів етичного кодексу педагога.

Низький рівень: відсутність чуйності, ввічливості, щирості, гуманності, тактовності, теплоти, відсутність у пріоритетах чесності і порядності, орієнтир на вирішення власних проблем, задоволення власних потреб, грубе порушення законів моралі і моральності, а також етичного кодексу педагога.

Висновки 3 даного дослідження. Таким чином, на основі теоретичного аналізу літератури 3 питання дослідження індивідуально-особистісних особливостей педагогів за допомогою контент-аналізу виявлено головні 3 них. Після об'єднання їх у блоки визначено та обгруновано критерії i відповідні ним показники щодо оцінки сформованості психологічної готовності майбутніх педагогів до професійної самореалізації.

\section{Перспективи подальших розвідок у} даному напрямі. Подальше дослідження зазначеної проблематики може фокусуватися за такими напрямками як дослідження взаємозв'язку професійної самореалізації молодих педагогів 3 їхнею первинною адаптацією, вивчення основних шляхів та засобів гармонізації професійного та особистісного аспектів самореалізації, а також психологічних умов корекції їхніх домагань в умовах недостатнього професійного досвіду.

\section{Перелік використаних джерел:}

1. Артемова $\quad$ O. I. Професійна самореалізація особистості в сучасних умовах / О.А. Артемова Український науковий журнал «Освіта регіону» Політологія, психологія комунікації. - №1, 2010. [Електронний ресурс]. - Режим доступу: http://social- 
science.com.ua/article/186

2. Боринштейн Е. Р. Особенности самореализации личности в современном украинском обществе /Е.Р. Боринштейн// Актуальні проблеми філософії та соціології. Серія : Філософія. - 2014. - Вип. 2. - С. 29-35.

3. Пилипенко Н. Психологічні особливості самореалізації особистості в умовах професійної кризи /Н.Пилипенко// Соціальна психологія. - 2005. - № 3. - С. 72-79.

4. Садова М. А. Професійна самореалізація особистості: біографічний аспект /М.А. Садова// Соціальні технології: актуальні проблеми теорії та практики: міжвузівський збірник наукових праць. - Одеса: Астропринт, 2008. - Вип. 39-40. - С. 291-296 с.

5. Долгих Л. Кар'єрні домагання як суб'єктивний механізм професійної самореалізації /Л.Долгих // Соціальна психологія. - 2005. - №2. - С. 64-71.

6. Алешина И. Ш. Уровень притязаний студентов педвуза с различными акцентуациями характера : дисс. ... канд. психол. наук : 19.00.07 - педагогическая психология / Ирина Шамильевна Алешина. - М., 2003. $-139 \mathrm{c}$.

7. Федяев A. A. Соотношение уровня притязаний, мотивации достижения и самооценки на этапе профессионального становления личности : дисс. ... канд. психол. наук : 19.00.13 - психология развития, акмеология / Андрей Анатольевич Федяев. - СанктПетербург, 2005. - 229 с.

8. Шумихина А. В. Притязания студентов-психологов в связи с особенностями их я-концепций : дисс. ... канд. психол. наук : 19.00.01 - общая психология, психология личности, история психологии / Анна Владимировна Шумихина. - Ростов-на-Дону, 2009. - 201 с.

9. Максименко С. Д. Теоретичні проблеми самоздійснення особистості /С.Д. Максименко, К.С. Максименко// Проблеми сучасної психології : зб. наук. пр. Ін-ту психології імені Г.С. Костюка НАПН України ; Кам'янець-Подільського нац. ун-ту імені Івана Огієнка. - К., 2009. - Вип. 5. - С. 3-13.
10. Максименко С. Д., Осьодло, В.І. Структура та особистісні детермінанти професійної самореалізації суб'єкта /С.Д. Максименко, В.І. Осьодло// Проблеми сучасної психології: Збірник наукових праць Кам'янець -Подільського національного університету імені Івана Огієнка, Інституту психології ім. Г.С. Костюка АПН України / За ред. С.Д. Максименка, Л.А. Онуфрієвої. Вип. 8. - Кам'янець-Подільський: Аксіома, 2010. - С. 319.

11. Роджерс K. Становление личности. Взгляд на психотерапию / К. Роджерс. Пер. с англ. М. Злотник. М.; Изд-во Эксмо-Пресс, 2001. - 416 с.

12. Маркова A. K. Психология труда учителя. Книга для учителя / А.К. Маркова. - М.: Просвещение, 1993. - 192 c.

13. Платонов K. К. Структура и развитие личности / К.К. Платонов. - М.: Наука, 1986. - 481 с.

14. Питерская $O . \quad$ B. Психологические основания успешности самореализации личности в особых видах труда : дис.. канд. психол.. наук : 19.00.01 - общая психология, психология личности, история психологии / Оксана Владимировна Питерская. Барнаул. - 161 с.

\section{References (Transliteration):}

1. Artemova O. I. Profesiyna samorealizatsiya osobistosti v suchasnih umovah / O.A. Artemova UkraHinskiy naukoviy zhurnal «Osvita regionu» Politologiya, psihologiya komunikatsiнi. - \#1, 2010. [Elektronniy resurs]. - Rezhim dostupu: http://social-science.com.ua/article/186

2.Borinshteyn E. R. Osobennosti samorealizatsii lichnosti v sovremennom ukrainskom obschestve /E.R. Borinshteyn// AktualnI problemi fllosofiyi ta sotsiologiyi. - Seriya : Filosofiya. - 2014. - Vip. 2. - S. 29-35.

3.Pilipenko $N$. Psihologichni osoblivosti samorealizatsiyi osobistosti v umovah profesiynoyi krizi /N.Pilipenko// Sotsialna psihologiya. - 2005. - \# 3. - S. 72-79.

4.Sadova M. A. Profesiyna samorealizatsiya osobistosti: 
biografichniy aspekt/M.A. Sadova// SotsialnI tehnologiyi: aktualni problemi teoriyi ta praktiki: mizhvuzivskiy zbirnik naukovih prats. - Odesa: Astroprint, 2008. - Vip. 39-40. S. 291-296 s.

5.Dolgih L. Kar'erni domagannya yak sub'ektivniy mehanizm profesiynoyi samorealizatsiyi /L.Dolgih // Sotsialna psihologiya. - 2005. - \#2. - S. 64-71.

6.Aleshina I. Sh. Uroven prityazaniy studentov pedvuza $\mathrm{s}$ razlichnyimi aktsentuatsiyami haraktera : diss. ... kand. psihol. nauk : 19.00.07 - pedagogicheskaya psihologiya / Irina Shamilevna Aleshina. - M., 2003. - 139 s.

7. Fedyaev A. A. Sootnoshenie urovnya prityazaniy, motivatsii dostizheniya i samootsenki na etape professionalnogo stanovleniya lichnosti : diss. ... kand. psihol. nauk : 19.00.13 - psihologiya razvitiya, akmeologiya / Andrey Anatolevich Fedyaev. - Sankt-Peterburg, 2005. - 229 s.

8.Shumihina A. $V$. Prityazaniya studentov-psihologov v svyazi s osobennostyami ih ya-kontseptsiy : diss. ... kand. psihol. nauk : 19.00.01 - obschaya psihologiya, psihologiya lichnosti, istoriya psihologii / Anna Vladimirovna Shumihina. - Rostov-na-Donu, 2009. - 201 s.

9.Maksimenko S. D. Teoretichni problemi samozdIysnennya osobistosti /S.D. Maksimenko, K.S. Maksimenko// Problemi suchasnoyi psihologiyi : zb. nauk. pr. Intu psihologiyi imeni G.S. Kostyuka NAPN Ukrayini ; Kam'yanets-Podilskogo nats. un-tu imeni Ivana Ogienka. K., 2009. - Vip. 5. - S. 3-13.

10.Maksimenko S. D., Osodlo V. I. Struktura ta osobistisni determinanti profesiynoyi samorealizatsiyi sub'ekta /S.D. Maksimenko, V.I. Osodlo// Problemi suchasnoyi psihologiyi: Zbirnik naukovih prats Kam'yanets-Podilskogo natsionalnogo universitetu imeni Ivana Ogienka, Institutu psihologiyi im. G.S. Kostyuka APN Ukrayini / Za red. S.D. Maksimenka, L.A. Onufrievoyi. - Vip. 8. - Kam'yanetsPodilskiy: Aksioma, 2010. - S. 3-19.

11. Rodzhers K. Stanovlenie lichnosti. Vzglyad na psihoterapiyu / K.Rodzhers. Per. s angl. M. Zlotnik. - M.; Izd-vo Eksmo-Press, 2001. - $416 \mathrm{~s}$.

12. Markova A. K. Psihologiya truda uchitelya. Kniga dlya uchitelya / A.K. Markova. - M.: Prosveschenie, 1993. - 192
S.

13. Platonov K. K. Struktura i razvitie lichnosti / K.K. Platonov. - M.: Nauka, 1986. - 481 s.

14. Piterskaya $O$. V. Psihologicheskie osnovaniya uspeshnosti samorealizatsii lichnosti v osobyih vidah truda : dis.. kand. psihol.. nauk : 19.00.01 - obschaya psihologiya, psihologiya lichnosti, istoriya psihologii / Oksana Vladimirovna Piterskaya. - Barnaul. - $161 \mathrm{~s}$.

\section{Gurtovenko Natalia}

Teacher of psychology of the Uman medical college, Uman (Ukraine)

\section{CRITERIA OF ESTIMATION, INDEXES AND LEVELS OF PSYCHOLOGICAL READINESS OF FUTURE TEACHERS TO PROFESSIONAL SELF-REALIZATION}

\section{ABSTRACT}

The choice of criteria of estimation is grounded in the article, indexes and levels of readiness to professional self-realization for future teachers. It is marked that professional self-realization is a search and being of the place in the system of human knowledge, achievements of the put aims in professional activity, and also personality self-determination. Professional selfrealization envisages a change itself, own professional position, overcoming of obstacles that arise up in professional activity. Psychological readiness of future teacher to professional self-realization is a presence of certain individually-personality qualities on the base of that there is a process of preparation to professional self-realization during his studies in university and forming professionally of important qualities of personality. Selection of 
blocks of qualities necessary for formed of psychological readiness to professional selfrealization allowed to define and ground the criteria of estimation with corresponding to them indexes: communicative criterion (ability to put right a contact and co-operate with a fellow creature on verbal and empathy levels); emotionallyvolitional criterion (empathy, mood, emotional firmness, firmness to the stress situations, blitheness, proof psyche etc.); an intellectuallysemantic criterion (is a high level of intellect, erudition, developed thinking, analytical composition of mind, reflection); motivational-cognitive criterion (creativity, adequate self-appraisal, ingenuity, high level of motivation of achievement, curiosity, initiativeness, aspiring to selfdevelopment and self-realization); mental and ethical criterion (sensitiveness, responsibility, politeness, tactfulness, humaneness, honesty, altruism, disinterestedness, goodwill, industriousness, sincerity, humaneness).

Key words: criterias of estimate, indicators, levels of readiness, psychological readiness, professional self-realization, future teachers.

\section{Гуртовенко Наталия Викторовна}

Преподаватель психологии Уманского медицинского колледжа, г. Умань (Украина)

\section{ПСИХОЛОГИЧЕСКОЕ СОДЕРЖАНИЕ И ФАКТОРЫ ОДИНОЧЕСТВА ЛИЧНОСТИ}

\author{
Аннотация. В статье обосновывается \\ выбор критериев оценки, показателей и
}

уровней готовности к профессиональной самореализации у будущих педагогов. Отмечается, что профессиональная самореализация - это поиск и нахождение своего места в системе человеческих знаний, достижения поставленных целей в профессиональной деятельности, а также личностное самоопределение. Профессиональная самореализация предусматривает изменение себя, собственной профессиональной позиции, преодоления препятствий, которые возникают в профессиональной деятельности. Психологическая готовность будущего педагога к профессиональной самореализации представляет собой наличие определенных индивидуально-личностных качеств, на базе которых происходит процесс подготовки к профессиональной самореализации во время его учебы в виші и формированию профессионально важных качеств личности. Выделение блоков качеств, необходимых для сформированности психологической готовности к профессиональной самореализации позволило определить и обосновать критерии оценки с соответствующими им показателями: коммуникативный критерий (умение наладить контакт и взаимодействовать с ближним на вербальном и емпатійному уровнях); эмоциональноволевой критерий (емпатія, настроение, эмоциональная стойкость, стойкость к стрессовым ситуациям, жизнерадостность, стойкая психика и т. п.); интеллектуально- 
смысловой критерий (высокий уровень интеллекта, эрудиция, развитое мышление, аналитический состав ума, рефлексия); мотивационно-познавательный критерий (креативность, адекватная самооценка, изобретательность, высокий уровень мотивации достижения, любознательность, инициативность, стремление к саморазвитию и самореализации); морально-этический критерий (чуткость, ответственность, вежливость, тактичность, человечность, честность, альтруизм, бескорыстие, доброжелательность, трудолюбие, искренность, человечность).

Ключевые слова: критерии оценки, показатели, уровни готовности, психологическая готовность, профессиональная самореализация, будущие педагоги. 